1 2 3

\title{
Challenges and Opportunities for Solar Tower Technology in India
}

\author{
Srilakshmi Gopalakrishnan ${ }^{\mathrm{a}, *}$; Venkatesh V ${ }^{\mathrm{a}}$; Thirumalai N C ${ }^{\mathrm{a}}$; Suresh N S \\ ${ }^{a}$ Center for Study of Science, Technology and Policy, $10^{\text {th }}$ Cross, Papanna Layout, Mayura Street, \\ Outer Ring Road, Bangalore, Karnataka, India -560 094
}

\begin{abstract}
Solar Tower technology has gained considerable momentum over the past decade. Unlike the parabolic trough, Solar Tower has a lot of variants in terms of type of receivers, working fluids, power cycles, size of heliostats, etc. Most of the literature available on this technology does not address in great depths, details of various parameters associated with tower technology. A detailed examination of plant parameters is required in order to perform a potential assessment, design basis or feasibility analysis. This paper aims to assess the principal parameters of existing plants, namely, solar to electric conversion efficiency, mirror and land area per $\mathrm{MW}_{\mathrm{e}}$ of equivalent capacity, packing density, field layout configuration, receiver size, tower height and gross costs of plants, wherever data is available. Based on this global review of existing plants, it is observed that, the annual solar to electric conversion efficiencies has an average value of $16 \%$ and an average packing density of about $20 \%$. Since most of the existing plants have been constructed for demonstration purposes, the true potential of this technology has not yet been realised. Using this assessment as a basis, the technical, financial and policy drivers and barriers for adopting tower technology in India are discussed. It is seen that based on indigenisation prospects, tower technology with external cylindrical or cavity receivers with storage could be adopted. The role and significance of this technology is brought out in the context of the Jawaharlal Nehru National Solar Mission (JNNSM) in order to achieve grid-connected solar power. It is estimated that around $1800 \mathrm{MW}$ of grid connected Solar Tower plants could come up under this mission by 2022 .
\end{abstract}

Keywords: Solar Tower; Global Review; Operational; Under Construction; India; JNNSM;

*Author for correspondence. Tel. +91-80-6690-2594, Fax: +91-80-2237-2619

E-mail address: srilakshmi@cstep.in 


\section{Introduction}

Solar Tower (ST) technology, which is also referred as Central Receiver Technology, uses a large number of heliostats having a dual axis control system (one about the elevation axis and the other about the azimuthal axis). These heliostats reflect direct beam solar radiation (impinging on their surface) to a stationary receiver located at the top of a tower. In the receiver, Heat Transfer Fluid (HTF) gains heat and transfers this thermal energy to the power block to generate electric power. This technology has evolved over the past 20 years. Even though it dates back to the late 1980s, over the past decade, a considerable increase in the number of operational ST plants has been observed. The capacity of plants under construction indicates that the growth of ST technology is on par with that of Parabolic Trough (PT) technology [1].

This paper presents an analysis of the challenges, opportunities and potential of ST technology for Indian conditions, based on a gross assessment of certain parameters of existing plants worldwide. Based on available information, solar to electric conversion ratio, mirror and land area variations with equivalent capacity, field layout configurations, working fluids employed, receiver size estimation, tower height, and gross costs of plants have been examined. Furthermore, an assessment of available solar and land resources in India, technological expertise in terms of engineering, design and manufacturing have also been discussed. Based on this assessment, the potential of ST technology for Indian conditions is estimated.

Most of the literature available on the existing ST plants discuss the overview, plant construction and characteristics [2],[3],[4],[5]. Studies have also been conducted on operation evaluation, modelling and simulation of specific components of plants [6],[7]. A design of reference plants using particular heliostats have been proposed [8]. Also, specific reviews of ST plants [9] as well as reviews of all the Concentrated Solar Power (CSP) technologies (which includes ST) have been performed [10],[11].

While most of the literature identified, discuss in depth, the performance characterisation of components of particular plants, they do not present a methodological assessment of ST parameters. In this paper, a detailed assessment of various parameters of existing ST plants is presented. This is used to infer the challenges and opportunities for employing ST technology in the Indian context.

The total installed capacity of ST plants worldwide is shown in Table 1. It has been compared with PT technology to identify the growth potential of ST in the next few years.

In India, the experience with ST is very limited and is yet to gain momentum. The Jawaharlal Nehru National Solar Mission (JNNSM), one of the eight missions under the Prime Minister's National Action Plan for Climate Change (NAPCC), was released in 2010. The objective of this mission is to achieve $20 \mathrm{GW}$ of grid-connected solar power and $2 \mathrm{GW}$ of off-grid solar power by 2022 . The targets set by JNNSM on capacity addition, is shown in Table 2. Planning supported by technology improvement and policy support can lead to high level of solar additions in India.

Section 2 of this paper discusses the assessment of existing plants based on various parameters like solar to electric conversion efficiencies, mirror \& land area used for various ST technologies, field layout, tower height etc. Section 3 discusses the challenges and opportunities for ST in India based on technical, financial and policy perspectives for critical parameters. This is done in terms of resource availability (solar and land) and technological expertise (engineering, design and manufacture). 


\section{Assessment of Existing Plants}

Tables 3 and 4, provide information on certain parameters of existing plants, both in operation and under construction. Based on the information available, assessment of the ST plants was carried out, and is discussed in this section.

\subsection{Overall Efficiency of Conversion of Solar to Electric Energy}

The solar to electric conversion efficiency of any plant is defined using Eq. (1).

$$
\eta_{S-e}=\frac{\text { Annual Electricity Generation }(M W h)}{\text { Annual Solar Resource }\left(M W h / m^{2}\right) \times \text { Heliostat Field Area }\left(m^{2}\right)}
$$

The values of conversion efficiency for various existing plants are calculated and shown in Table 5. In this table, the last column contains calculated values while the other columns contain collated data [13]. It is broadly segregated based on the type of receiver being employed for operational plants and plants under construction. From the table, it is seen that $\eta_{s-e}$ lies in the range of $15.51 \%$ to $17.30 \%$.The Jülich plant has a very low conversion efficiency of $6.16 \%$. This is because air is used as the HTF, which transfers its thermal energy to water. The steam generated in the process drives a Rankine cycle. This is an inept process as the efficiency of heat transfer from air to water/steam is quite low. The average value of $\eta_{s-e}$, from Table 5 is found to be about $16 \%$.

\subsection{Comparison of Heliostat Field Area and Land Area with respect to Equivalent Capacity}

The mirror area and land area per $\mathrm{MW}_{\mathrm{e}}$ of rated capacity varies due to the number of thermal storage hours employed. Hence there is a necessity to normalise the mirror and land area taking into consideration the number of hours of thermal storage. In order to do this, it is assumed that with no thermal storage, a typical plant can operate for around nine hours [14],[15],[16]. If $x$ hours of thermal storage are incorporated, then the capacity increases by $(9+x) / 9$ times as compared to a similar plant with no thermal storage. We define this as the equivalent capacity (in $\mathrm{MW}_{\mathrm{e}}$ ) of the plant, given by $\mathrm{Eq}$. (2).

$$
\text { Equivalent Capacity }=\text { Rated Capacity } \times\left(\frac{9+x}{9}\right)
$$

where, $x$ is the number of hours of thermal storage.

Mirror and land area were compared with rated and equivalent capacity for existing plants, separately, for each type of receiver used.

\subsubsection{Mirror Area}

Table 6 gives the values of the mirror area per $\mathrm{MW}_{\mathrm{e}}$ of rated and equivalent capacity.

It can be seen from the table that the mirror area per $\mathrm{MW}_{\mathrm{e}}$ of equivalent capacity $\left(\mathrm{m}^{2} / \mathrm{MW}_{\mathrm{e}}\right)$ of plants using cavity receivers ranges from about 6000 to 6750 and for plants using external receivers ranges from about 3800 to 6650. It can also be seen that both Rice Solar and Crescent Dunes plants have lesser mirror area/ $\mathrm{MW}_{\mathrm{e}}$ compared to other plants. This is because these two sites have higher solar resource (see Table 5). Even though the Ivanpah plant has the highest solar resource, its mirror area/MW $\mathrm{MW}_{\mathrm{e}}$ is also high since it employs the Direct Steam Generation (DSG) mode for attaining temperatures of the order of $565^{\circ} \mathrm{C}$. 
A plot of mirror area vs. equivalent capacity is shown in Fig. 1 for operational plants and the curve obtained was found to resemble a linear pattern.

\subsubsection{Land Area}

Table 7 shows the utilisation of land area per $\mathrm{MW}_{\mathrm{e}}$ of rated and equivalent capacity.

The land area per equivalent capacity (hectares/ $\mathrm{MW}_{\mathrm{e}}$ ) for plants with cavity receivers ranges from 1.3 to 4.5 and for plants with external receivers ranges from 2 to 3.7. Here, the variation could be due to the type of receiver employed, height of the tower, sizes of heliostats used, and further, due to the variations in packing density.

A similar plot (as presented in Fig. 1) showing variation of land area with equivalent capacity is given in Fig. 2, which also indicates a linear variation.

\subsubsection{Packing Density}

The packing density of a plant is defined as the ratio of mirror area to land area. It gives an indication of the extent of utilisation of land. Packing density percentage is defined in Eq. (3).

Packing density percentage $=\frac{\text { Mirror Area }}{\text { Land Area }} \times 100$

In Table 8, the packing density of existing plants (segregated based on type of field configuration) has been calculated and presented. It can be observed that the average value of packing density for operating plants is about $20 \%$.

\subsection{Field Layout Configuration}

There are some standard layout patterns which have been observed for the heliostat field design of existing plants. These are: radial staggered and cornfield patterns.

\subsubsection{Radial staggered}

In this configuration, heliostats are arranged in a circular manner around the tower. This can be seen in Fig. 3, which is the heliostat field of the Gemasolar plant. In Fig. 4, the field for PS 10 and PS 20 towers have been shown. As seen in the radial staggered configuration, the arrangement is such that no two heliostats in adjacent rings are on the same radial line. Consecutive circular rings position heliostats in a staggered formation of this kind. They are typically employed for plants using external cylindrical receivers with surround field layouts or cavity receivers with northern fields.

\subsubsection{Cornfield}

A cornfield layout, as the name suggests, refers to a configuration where the heliostats are arranged in straight rows, one behind the other. This is shown in Fig. 5 (the Sierra Sun Tower) and Fig. 6 (the Jülich tower). In Fig. 6, a single-side field is used, since the Jülich tower uses a cavity receiver with a single-side aperture.

\subsubsection{Observations on field layouts of existing plants}

From Figs. 3 to 6, one can infer that the layout of heliostats does not follow any particular norm. Depending on the plant capacity, type of receiver used, as well as the latitude of the plant, the 
heliostat field layout changes. It is interesting to note that all these plants (except Dahan and Jülich) are located in the latitude range of $28^{\circ} 11^{\prime} \mathrm{N}$ to $38^{\circ} 14^{\prime} \mathrm{N}$. However, their layouts are different because different types of receivers are used. At these latitudes, the sun is due south throughout the year. Therefore in the PS 10, PS 20, ACME, Dahan and Solugas plants, using single cavity receivers, it is appropriate to locate all heliostats to the north of the tower. The Gemasolar plant uses an external cylindrical receiver and consequently the heliostats are located all around the tower (surround field), but a greater number of heliostats are on the northern side.

The ratio of the radial distance of the farthest heliostat $(r)$ and the height of the tower $(h)$ is shown in Table 8. The $r$ values were estimated from the Google Maps and Wikimapia images [17], [18], [19], [20] and the $h$ values were taken from the NREL database [13]. The $r / h$ ratio for the Gemasolar plant on the north side of the field is 6.1 whereas on the south side it is 4.3. Sierra SunTower has two units, one uses an external cylindrical receiver and the other uses a dual cavity receiver [13]. The maximum $r / h$ ratio seen in both cases is 2.3 . Thus, the heliostat field layout is closely linked with the choice of the receiver and other design considerations.

The size of the heliostat also plays a key role in determining the field layout. It can be seen that the Sierra Sun Tower heliostats with cornfield pattern are more closely packed (leading to a high packing density, See Table 8). The Jülich plant also has a cornfield pattern and relatively high packing density. It can be seen from Table 8, that plants with cornfield pattern have better land utilisation compared to plants with radial patterns.

For plants with radial staggered configurations (surround/north fields) and large heliostats, for example, PS 10, PS 20 and the Gemasolar plant, the packing densities are smaller. When the heliostat size increases, the shadowing and blocking effects increase. If these have to be minimised, the mirrors will have to be placed at large distances from each other, thereby reducing the packing density.

\subsection{Working Fluid Employed}

Different types of HTFs can be used in an ST plant based on the type of receiver and power cycle employed in the system. HTFs that have been used in existing operational ST plants are water, molten salt and air.

\subsubsection{Water}

When water is used as HTF, the solar field generates steam directly and the Rankine steam cycle is used for power generation. Since in this case, water is used both as HTF and working fluid, it eliminates the need for a heat exchanger. The maximum possible temperature that has been achieved with water is $566^{\circ} \mathrm{C}$ [13]. Plants using water as HTF are PS 10, PS 20, Dahan, Sierra Sun Tower and Ivanpah.

\subsubsection{Molten Salt}

In the case of molten salt as HTF, a heat exchanger is used to transfer thermal energy from the HTF to water in order to generate steam. Steam Rankine cycle is used for power generation. One of the advantages of using this as the working fluid is that the HTF used is same as the storage media. When the plant is not in operation, HTF from the receiver has to be drained out as the freezing temperature of molten salt is relatively high, its value being around $238^{\circ} \mathrm{C}$ [21]. Gemasolar plant uses molten salt as its HTF. This is also because it employs 15 hours of thermal storage. 


\subsubsection{Air}

Air is used as the HTF when a volumetric receiver is used. The receiver design is rather complex with one disadvantage being that air has poor heat transfer properties. Therefore, the efficiency of heat transfer to the power block is not very high. Compressed air has better heat transfer properties as it is denser. Air at high temperatures of the order of $1000^{\circ} \mathrm{C}$ gives rise to better heat transfer properties but the material constraints of the HTF carrying pipes will have to be considered. Also air does not require cooling water and hence is advantageous especially in locations where water availability is a problem. Jülich tower in Germany uses a volumetric receiver, with air as HTF and water as working fluid. This plant employs a steam Rankine power cycle. Since the advantage of air reaching high temperatures is not completely utilised, low power block efficiencies are observed in this case.

The advantages and limitations of the working fluids mentioned in this Section are shown in Table 9.

\subsection{Estimation of Receiver Size}

It is observed from the literature review that a basis for sizing the receiver and arriving at an optimum size of the receiver was not explicitly available. In this section, a methodology has been arrived at, for a first order estimation of receiver size. This is based on the equivalent capacity of a plant, the type of HTF used, and operating temperatures. The actual receiver size is higher than the estimated one as it accounts for spillages, varying flux distributions, thermal losses, etc. Based on the actual receiver size (from existing plant data), the factor by which it is higher than the estimated area has been arrived at (see Eq. (7)). Table 10 presents the estimation of receiver size. The values assumed for the power block efficiency are shown in this table. From this, the power input to the power block $\left(\mathrm{MW}_{\mathrm{th}}\right)$ is estimated as shown in Eq. (4).

$$
\text { Thermal power input to the power block }\left(P_{\text {input }, P B}\right)=\frac{\text { Equivalent Capacity }}{\eta_{P B}} \times 100
$$

where, Equivalent Capacity is in $\mathrm{MW}, P_{\text {input }, P B}$ is in $\mathrm{MW}_{\text {th }}$ and $\eta_{P B}$ is the power block efficiency percentage.

The receiver efficiency is in the range of $80 \%$ to $90 \%$. For this study, it is assumed to be $85 \%$ [23] and therefore, the thermal power input to the receiver from the solar field $\left(\mathrm{MW}_{\mathrm{th}}\right)$ is given in Eq. (5).

$$
\text { Thermal power input to the receiver }\left(P_{\text {input, }, \text { receiver }}\right)=\frac{P_{\text {input }, P B}}{85} \times 100
$$

where, $P_{\text {input,receiver }}$ is in $\mathrm{MW}_{\text {th. }}$.

Depending on the type of HTF used, the maximum allowable flux density on the receiver is fixed. For safety conditions, it has been assumed that approximately $85 \%$ of this maximum allowable flux is incident on the receiver. The calculated receiver area is obtained from Eq. (6).

$$
\text { Calculated Receiver Area }=\frac{P_{\text {input }, \text { receiver }}}{\text { Flux on receiver }} \times 1000
$$

where, Flux on receiver is in $\mathrm{kW} / \mathrm{m}^{2}$.

This calculated receiver area is compared with the actual receiver area of various plants - Jülich, PS10, Solar Two and Gemasolar [24], Dahan [7], Solugas [25], which is available in the literature.

There is a limitation on the maximum allowable flux density for various HTFs. For molten salt, it is $1000 \mathrm{~kW} / \mathrm{m}^{2}$ [26], for water it is $350 \mathrm{~kW} / \mathrm{m}^{2}$ [23] and for air it is assumed to be $1200 \mathrm{~kW} / \mathrm{m}^{2}$.

The ratio of actual receiver size and calculated receiver size is given in Eq. (7) is computed. 
This ratio varies from 1.47 to 2.31 for plants using molten salt, 0.96 to 1.57 for plants with water and 2.86 and 5.10 for plants with air as HTF as shown in Table 10. It can be seen that this ratio is high for receivers using air as $\mathrm{HTF}$. These receivers can attain temperatures of $1000^{\circ} \mathrm{C}$. Due to the lower heat capacity of air, these plants require receivers with bigger surface area compared to receivers using water as HTF.

\subsection{Tower Height}

Table 11 lists the tower heights $(h)$ of ST plants. Fig. 7 shows the variation of tower height with equivalent capacity, with the numbers indicating the serial number of the plant given in Table 11. It is observed that no direct correlation is evident between the tower height and the equivalent capacity of a plant.

Once the capacity of a plant, its thermal storage and solar resource are known, the land and mirror areas can be determined. Based on the type of receiver and design of a plant, the heliostat field can be designed. However, the basis on which the height of the tower is arrived at is not clear. From Table 8, it can be seen that the ratio of the farthest distance of the heliostat to the tower height $(r / h)$ is between 5.7 and 6.8 for most of the plants. However, for the Ivanpah plant, it is higher (of the order of 10), while for the Sierra Sun tower plant and the Jülich plant, it is a much smaller value, 2.3.

\subsection{Gross Cost of Existing Plants}

The data available on the gross costs for existing tower plants is limited. The gross cost of the PS 10 plant (cavity receiver) is about Rs 19 crores per $\mathrm{MW}_{\mathrm{e}}$ (35 million Euros [27]). The gross cost for the Dahan plant (cavity receiver) is approximately Rs 20 crores per $\mathrm{MW}_{\mathrm{e}}$ (32 million CNY [28]). The overall cost of the Gemasolar plant (external cylindrical receiver) is approximately Rs 36 crores per $\mathrm{MW}_{\mathrm{e}}$ (419 million USD [29]). This data is depicted in Table 12. Data for most of the other existing plants was not available. 


\section{Challenges and Opportunities for ST Deployment in India}

This section discusses the challenges and opportunities for deployment of ST technology in India. This is analysed with respect to technical, financial and policy aspects for the following parameters, as applicable.

\subsection{Solar Resource}

\subsubsection{Technical}

Challenges: Solar resource data is available either through satellite or ground based measurements. At present, for India, ground-based measurements are available for 119 stations [30]. On the other hand, satellite data is available for India from various sources [31],[32],[33],[34]. However, satellite data is not as accurate as solar resource data obtained from ground-mounted sensors. Satellite-based models cannot provide accurate instantaneous values like the ground-based measurements. They also provide data with lower frequency of measurement [35]. Therefore, ground-based data is required for many more stations in India, such that accurate pre-feasibility analyses can be carried out to identify the potential locations for installations of ST technology.

As seen, in Table 8, the $r / h$ ratios are such that the farthest heliostat can be as much as a km away from the tower. When a sun ray is reflected from such a large distance, it is bound to undergo attenuation losses. These losses occur due to the scattering and diffusion of reflected solar radiation by aerosols, moisture content and dust in the atmosphere. As the particulate matter content of the atmosphere increases, so does the attenuation loss. [36].

Most areas in India which have abundant solar irradiation (for example, Gujarat and Rajasthan) are also areas which are prone to very high dust factors. Dust in the atmosphere, not only causes attenuation losses but also settles on the heliostats, thereby reducing their life and efficiency. In these cases, maintenance of each heliostat (mirror cleaning) is of prime importance and this is not an easy task in a field with thousands of mirrors.

Opportunities: Most parts of India receive high solar resource, i.e., Direct Normal Irradiance (DNI) almost throughout the year, which has the potential to be tapped. The best sites in India receive around $2100 \mathrm{kWh} / \mathrm{m}^{2} /$ annum. [14]. As noted from the assessment, this is on par with all the existing plants that are producing grid connected power. These sites have solar resources of the same order, the average being around $2230 \mathrm{kWh} / \mathrm{m}^{2} /$ annum (See Table 5). This sets the benchmark for commercial viability of this technology under Indian conditions.

As can be seen from Section 2, the geographical location of a plant has a bearing on the type of receiver and heliostat field configuration used. The position and path of the sun depend on the latitude of the given location.

India is situated approximately between $8^{\circ} \mathrm{N} \& 34^{\circ} \mathrm{N}$ latitude and $70^{\circ} \mathrm{E} \& 96^{\circ} \mathrm{E}$ longitude. Two nomograms have been prepared considering the extreme latitudes of $8^{\circ} \mathrm{N}$ and $34^{\circ} \mathrm{N}$ to illustrate the path of the sun over the year. These nomograms are shown in Fig. 8 for days of Mar 21, July 21 and Dec 21 . The radial lines indicate the azimuth position of the sun whereas the concentric circles 
represent the altitude angle of the sun. From these nomograms, it can be seen that the sun stays predominantly due south for most of the year. Considering all these facts, cavity receiver with northern field could be ideal for smaller plant capacities $(<20 \mathrm{MW})$. This is also evident from assessment in Section 2 (see Table 3). Similarly, external cylindrical receivers with surround heliostat field and dual cavity receivers are suitable for higher capacity plants (>20 MW).

India receives around 300 sunny days in a year [14], thus enabling harnessing of solar energy for the setting up of power plants. Fig. 9 shows the DNI Map of India. It can be seen from this map, that most parts of India enjoy a daily solar radiation of $4.5-5 \mathrm{kWh} / \mathrm{m}^{2} /$ day. Out of the 3.28 million $\mathrm{km}^{2}$ of land area that India spans, around $18 \%$ receives solar radiation of $5.5-6 \mathrm{kWh} / \mathrm{m}^{2} /$ day which is suitable for solar thermal power generation. This land area might include forests, agricultural land, waste land, built up area, water bodies etc.

\subsection{Land Resource}

\subsubsection{Technical}

Challenges: Micro-siting of wastelands has not been conducted for all states in India. This needs to be performed in order to estimate the potential or possibility of ST technology by assessing terrain, soil, wind conditions etc. The proximity of wastelands from the load centers is not explicitly available. The wasteland locations have to be coupled with matrices like sub-stations, water availability and road connectivity in order to identify suitable wastelands for ST installations.

Opportunities: Approximately 0.4 million $\mathrm{km}^{2}$ of wasteland is available in India [38]. From the assessment (see Table 7), it is seen that for existing ST plants with grid connected power, the average land requirement per $\mathrm{MW}_{\mathrm{e}}$ is 3.8 hectares $\left(0.038 \mathrm{~km}^{2}\right)$. Even if $1 \%$ of this wasteland is utilized, the potential for ST technology is around $105 \mathrm{GW}_{\mathrm{e}}$. Therefore, land should not pose as a constraint for ST deployment.

\subsubsection{Financial}

Challenges: Even though wastelands are available, acquisition challenges in terms of obtaining clearances, time for sanctioning land etc. are not very easy to obtain and these add to the total preoperative costs. If the terrain has a slope greater than $5^{\circ}$, then considerable earthwork would be required to be performed. This would lead to an increase in the construction time and the installation (set-up) cost.

Opportunities: Costs of wasteland are relatively cheap in India and would be of the order of about 1$2 \%$ of the total capital costs. [22].

\subsubsection{Policy}

Challenges: For zones which receive high DNI in India, land banks have not yet been identified. The Government needs to take initiative in ear marking land banks which have proximity to water resource and power evacuation facilities which are quintessential to large scale ST plants. There is a void in the policy support towards this which needs to be addressed.

\subsection{Technology}

\subsubsection{Technical}


Challenges: The maturity of ST technology is not very high in India. It is still in the nascent stages where R\&D work needs to be carried out. India has limited experience in the development of power tower systems. Apart from a couple of small-scale demonstration plants, there are no plants in the pipeline. ACME company in India partnered with eSolar company, USA, to develop a $2.5 \mathrm{MW}_{\mathrm{e}}$ tower plant in Bikaner, Rajasthan. The heliostat field for this plant set-up utilises $1.16 \mathrm{~m}^{2}$ small size flat mirrors [13]. The advantage of small size heliostats is that they are easy to handle and install, but a major disadvantage is that they require more number of controllers for tracking. Even though the plant, was commissioned in 2010, it has been running at reduced capacity [39]. Some of the possible problems that can be envisaged include lack of sufficient DNI, difficulties in tracking, and accumulation of dust on the mirrors.

SunBorne Energy is setting up a $1 \mathrm{MW}_{\text {th }}$ solar power tower system with the support of the Ministry of New and Renewable Energy (MNRE), Government of India at the National Institute of Solar Energy (NISE), Gurgaon. The primary aim of this demonstration plant is to devise a method to optimise the heliostat field (using Titan tracker heliostats) using a volumetric air receiver while simultaneously having a provision for thermal storage. This plant is planned to be set-up using regional indigenous resources for most of the system components [40].

Detailed studies need to be carried out to understand the suitable ST technology variants that are ideal for Indian conditions. The ground work required to make this technology more acceptable to the market has to be performed. Many of the existing plants that have been collated in this study are demonstration plants. Currently, only four plants are commercial plants, producing grid connected power.

Opportunities: In terms of technology that can be used for Indian conditions, the initial assessment (See Section 3.1.1) suggests that for India, plants with an external cylindrical receiver (with surround field) or cavity receiver (with north side field). Since plants employing these receivers have been commercially proven, these two technologies can be adopted for Indian conditions. High temperatures in the range of 300 to $1000^{\circ} \mathrm{C}$ are possible with the use of suitable HTFs leading to higher power cycle efficiencies.

Due to availability of biomass resource in India, hybridisation with biomass can be achieved in order to increase the Plant Load Factor (PLF) of the plants.

\subsubsection{Financial and Policy}

Challenges: Since ST technology is a new entrant in the power sector, and only a few demonstration plants have been built, the actual costs are not known. Bankability of this technology is also an issue in the Indian market. Hence, getting financial closure would be difficult in this case. Furthermore, there is a void in the policy framework for tariff support for implementation of power plants with storage and hybridisation. This is a deterrent to the growth of ST plants in India.

\subsection{Engineering \& Design}

\subsubsection{Technical Expertise in India}

Challenges: Companies specialising in design, implementation and construction of ST plants are currently not present in India and very few companies exist worldwide. The lack of domestic industry participation also hampers the investment that can be made in this technology. Not enough pilot projects have come up, in India, in order to gain a better understanding of the ST technology. 
Opportunities: India could have a head start in the designing and manufacturing of various components and further improvement through R\&D facilities. A gradual market can be built up. Meanwhile the advantages in importing various components of this technology can be examined.

\subsubsection{Manufacturing, Supply Chain \& Materials}

Challenges: Absence of an established supply chain for the main ST components is a major challenge. One of the most important components of ST technology, namely, the receiver, does not have even a single indigenous manufacturing unit in India. At the international level as well, there are only a handful of manufacturers, resulting in expensive receivers.

For the HTF, there are only three suppliers of molten salt globally, namely, SQM (Chile), Haifa Chemicals (Israel), and Durferrit Salts and Auxiliary Products (Germany). Lack of domestic suppliers for molten salt is a barrier in implementing ST plants with storage (as molten salt storage is the most efficient presently). This is due to the fact that molten salt is a major cost contributor of a storage system.

Unlike PT, which has a well-established supply chain, ST has limited suppliers as well as standards due to the large number of variants in technology. Furthermore there is no benchmarking for reliability testing of ST components. Due to this, market acceptability of in-house manufactured components is low. We can see that due to the lack of demand for components such as heliostats, receivers etc. for which a domestic market can be set up, the question of sustainability looms at large.

Opportunities: The manufacture of low cost heliostats is possible as there is considerable availability of low iron content glass in India, which is necessary for the fabrication of heliostats. The structural designing of the tower and manufacturing of heliostat support structures (requisite drive mechanisms) can be accomplished in India, at lower costs.

The establishment of an indigenous market for receiver technology (external cylindrical and cavity receivers) can be done as, once the specifications are known. Since India has a good engineering base, the manufacturing and fabrication process can be achieved.

\section{Conclusion}

The total capacity of grid-connected solar projects in India currently stands at $2632 \mathrm{MW}$ as on March 31, 2014 [41]. The contribution from CSP in Phase-1 has been very less compared to the contribution of photovoltaic systems. Some of the reasons for the slow deployment of CSP in India are: availability of solar resource data, delay in importing key components of the plant (mirrors, HTF, etc.), obtaining financial closure, etc. However, CSP is expected to play a significant role in the coming phases of JNNSM, given the mandate of 30\% capacity addition from CSP [12]. Assuming that $30 \%$ of the target could be tapped from solar thermal technologies, the share of CSP will be around $6000 \mathrm{MW}$. Based on present maturity levels of ST technology, it is assumed that it can contribute around $30 \%$ of the CSP share, resulting in approximately 1800 MW of installed capacity by 2022.

As seen from the existing plants, most of the tower plants employ either the external cylindrical or the cavity type receiver. By using molten salt, one can achieve higher temperatures along with thermal storage for a long duration. The main advantage of using molten salt is that it can be used both as the HTF and as well as the storage medium. 
Given the considerations mentioned above, the system configuration that could be ideal for Indian conditions are:

- Molten salt as both HTF and storage medium

- External cylindrical receivers with a larger north-side field, or cavity receivers with a northside field

- Thermal storage for utility scale plants as it can provide reliable and dispatchable power, and further help in meeting peak-time demands

- Biomass hybridisation

As discussed earlier, based on reasonable assumption, the share of ST technology deployment in India, is about $1800 \mathrm{MW}$ (of grid-connected power), which is to be achieved by 2022 . The assessment study concludes that this is an achievable target. Given the challenges with conventional methods of power generation, the use of tower technology in harnessing solar power will play a pivotal role in meeting India's future energy demands.

\section{Acknowledgements}

This paper is based on the work done at CSTEP supported in part under the US-India Partnership to Advance Clean Energy-Research (PACE-R) for the Solar Energy Research Institute for India and the United States (SERIIUS), funded jointly by the U.S. Department of Energy (Office of Science, Office of Basic Energy Sciences, and Energy Efficiency and Renewable Energy, Solar Energy Technology Program, under Subcontract DE-AC36-08GO28308 to the National Renewable Energy Laboratory, Golden, Colorado) and the Government of India, through the Department of Science and Technology under Subcontract IUSSTF/JCERDC-SERIIUS/2012 dated 22 ${ }^{\text {nd }}$ November, 2012. The authors are grateful to Dr Anshu Bharadwaj, Executive Director, CSTEP for his constant encouragement, support and guidance. The authors are also thankful to M A Ramaswamy, Advisor, CSTEP and Badri S Rao, Research Engineer, CSTEP for their critical review in improving the manuscript. 


\section{References}

[1] National Renewable Energy Laboratories (NREL). URL:

http://www.nrel.gov/csp/solarpaces/by_project.cfm [Accessed: January 2014].

[2] Burgaleta JI, Arias S, Ramírez D. Gemasolar - The first tower thermosolar commercial plant with moltern salt storage. In: SolarPACES, Granada, Spain, September 2011; 20-23.

[3] Koll G, Schwarzboezl P, Hennecke K, Hartz T, Schmitz M, Hoffschmidt B. The Solar Tower Jülich - A Research and Demonstration Plant for Central Receiver Systems. $15^{\text {th }}$ Proceedings SolarPACES 2009; September 2009, Berlin; 15 - 18

[4] Quero M, Korzynietz R, Ebert M, Jiménez AA, del Río A, Brioso JA. Solugas - Operation experience of the first solar hybrid gas turbine system at MW scale. SolarPACES: Energy Procedia 2013;000-000.

[5] Meduri PK, Hannemann CR, Pacheco JE. Performance Characterization and Operation of eSolar's Sierra Suntower Power Tower Plant. In: SolarPACES Conference 2010, Perpignan, France.

[6] Zunft S, Hänel M, Krüger M, Dreissigacker V, Göhring F, Wahl E. Jülich solar power tower experimental evaluation of the storage subsystem and performance calculation. ASME Journal of Solar Energy Engineering, 2011;133: 031019-1.

[7] Xu E,Yu Q,Wang Z,Yang C. Modeling and simulation of 1 MW DAHAN solar thermal power tower plant. Renewable Energy 2011; 36:848-57.

[8] Tyner C, Wasyluk D. eSolar's modular, scalable molten salt power tower reference plant design.SolarPACES: In: 19th annual SolarPACES symposium. 2013. Las Vegas; Energy Procedia 2013;000-000.

[9] Manuel Romero, Reiner Buck, James E. Pacheco. An Update on Solar Central Receievr Systems, Projects and Technologies. ASME 2002;124:98-108.

[10] Siva Reddy V, Kaushik SC, Ranjan KR, Tyagi SK, State of the Art Solar Thermal Power Plants A Review. Renewable and Sustanable Energy Reviews,2013;27:258-73

[11] Zhang HL, Baeyens J, Degrève J, Cacères G. Concentrated solar power plants: Review and design methodology. Renewable and Sustainable Energy Reviews 2013; 22:466-81.

[12] MNRE-Phase II-JNNSM Policy Document, December 2012. Url: http://mnre.gov.in/filemanager/UserFiles/draft-jnnsmpd-2.pdf [Accessed: February 2014].

[13] National Renewable Energy Laboratories (NREL). URL:

http://www.nrel.gov/csp/solarpaces/power_tower.cfm. [Accessed: January 2014].

[14] Mahtta R, Joshi PK, Jindal AK. Solar Power Potential Mapping in India using Remote Sensing Inputs and Environmental Parameters. Renewable Energy 71 (2014): 255-262.

[15] Khare V, Nema S, Baredar P. Status of Solar Wind Renewable Energy in India. Renewable and Sustainable Energy Reviews 27 (2013):1-10.

[16] Chandel M, Agrawal GD, Mathur S, Mathur A. Techno-Economic Analysis of Solar Photovoltaic Power Plant for Garment Zone of Jaipur city. Case Studies in Thermal Engineering 2 (2014):1-7.

[17] Wikimapia. URL: http://wikimapia.org/\#lang=en\&lat=37.564548\&lon=-5.326610\&z=15\&m=b [Accessed: February 2014]

[18] Wikimapia. URL: http://wikimapia.org/\#lang=en\&lat=37.445153\&lon=$6.255856 \& \mathrm{z}=16 \& \mathrm{~m}=\mathrm{b} \& \mathrm{search}=$ plant $\% 20$ solar\%2010\%20seville [Accessed: February 2014]

[19] Google Maps. URL: https://www.google.co.in/maps/@34.7314081,$\underline{118.1384052,238 \mathrm{~m} / \text { data }=! 3 \mathrm{~m} 1 ! 1 \mathrm{e} 3}$ [Accessed: February 2014] 
[20] Google Maps. URL:

https://www.google.co.in/maps/place/J\%C3\%BClich/@50.9148227,6.3878133,480m/data=!3m1!1e3! 4m2!3m1!1s0x47bf5955a9618aa3:0x3eefff6a1ed5a8f9 [Accessed: February 2014]

[21] Archimede Solar Energy URL: http://www.archimedesolarenergy.it/molten salt.htm. [Accessed: February 2014]

[22] Ramaswamy MA, Chandrasekaran VS, Krishnan R, Thirumalai NC, Suresh NS, Badri S R, Dolly SK, Kanth VC, Kumar VA. Engineering Economic Policy Assessment of Concentrated Solar Thermal Power Technologies for India. Banaglore: CSTEP 2012;162-4.

[23] Stein WB, Geyer M. Power from the Sun. URL: http://www.powerfromthesun.net/Book/chapter10/chapter10.html [Accessed: February 2014] [24] Augsburg G. Thermo-Economic Optimization of Large Solar Tower Power, EPFL 2013; Page 92.

[25] Quero M, Korzynietz R, Ebert M, Jiménez AA, del Río A, Brioso JA. Solugas - Operation experience of the first solar hybrid gas turbine system at MW scale. SolarPACES 2013: Energy Procedia 2013: 000-000.

[26] Hull V, Lorin L. The Role of "Allowable Flux Density" in the Design and Operation of Molten Salt Solar Central Receivers. Journal Solar Energy Engineering 2002;124:165-9.

[27] http://ec.europa.eu/research/energy/eu/index en.cfm?pg=research-csp-support. [Accessed: February 2014]. [28] NREL, URL: http://www.nrel.gov/csp/solarpaces/project_detail.cfm/projectID=253. [Accessed: February 2014].

[29] The Energy Collective, URL: http://theenergycollective.com/nathan-wilson/58791/20mwgemasolar-plant-elegant-pricey. [Accessed: January 2014]. [30] National Insititute of Wind Energy. URL: http://cwet.res.in/web/html/departments_srra.html. [Accessed: October 2014].

[31] National Renewable Energy Laboratories (NREL).

URL:http://rredc.nrel.gov/solar/new_data/India/

[32] Database Name: Meteonorm, Data Provider: Meteotest. URL: http://meteonorm.com/. [Accessed: February 2014].

[33] Database Name and Provider: Weather Analytics. URL: http://www.weatheranalytics.com/. [Accessed: February 2014].

[34] Database Name: Solemi, Data Provider: DLR. URL:www.dlr.de/tt/solemi. [Accessed: March 2014].

[35] Suri M, Cebecauer T. Satellite-based Solar Resource Data: Model Validation Statistics Versus User's Uncertainty. Presented at: ASES SOLAR 2014 Conference, San Francisco.

[36] Ballestrin J, Marzo A. Solar Radiation Attenuation in Solar Tower Plants. $17^{\text {th }}$ SolarPACES International Symposium 20-23 September 2011. Granada, Spain.

[37] National Renewable Energy Laboratories (NREL).

URL:http://www.nrel.gov/international/images/india_dni_annual.jpg

[38] Wastelands Atlas of India, Departement of Land Resources, national Remote Sensing Centre; 2011

[39] Down To Earth, URL: http://www.downtoearth.org.in/content/solar-thermal-technology-getboost-phase-two-solar-mission. [Accessed: December 2014]. [40] MNRE, URL: http://mnre.gov.in/centers/about-sec-2/new-initiatives/. [Accessed: February 2014].

[41]Renewable Energy Headlines, URL:

http://www.renewableenergyheadlines.com/index.php?option=com k2\&view=item\&id=2739:totalgrid-connected-solar-capacity-stood-at-2-632-mw-as-on-march-31-2014\&Itemid=103. [Accessed: February 2014] 


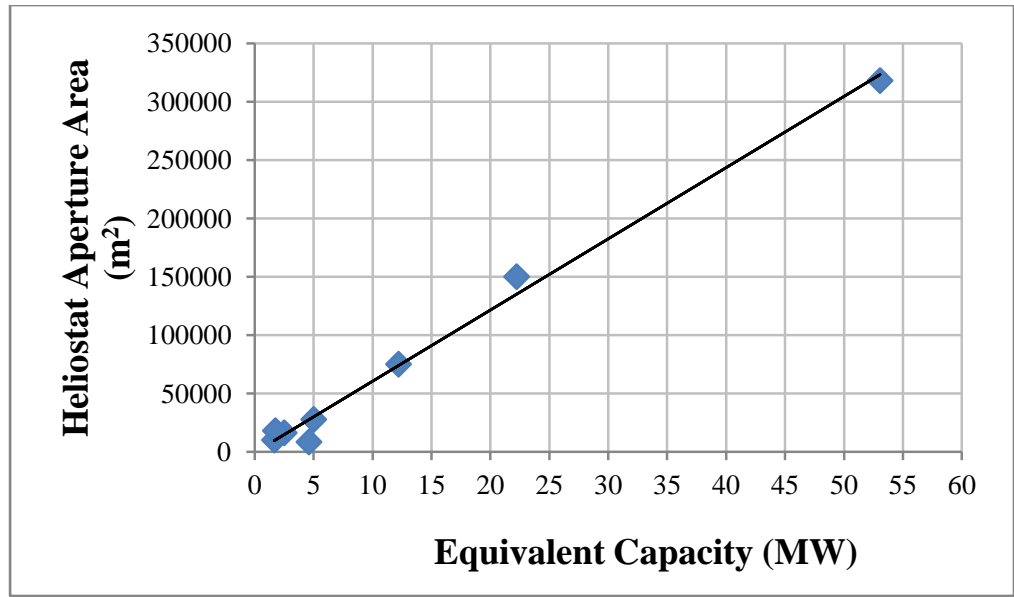

Fig. 1: Mirror Area vs. Equivalent Capacity for Operational Plants

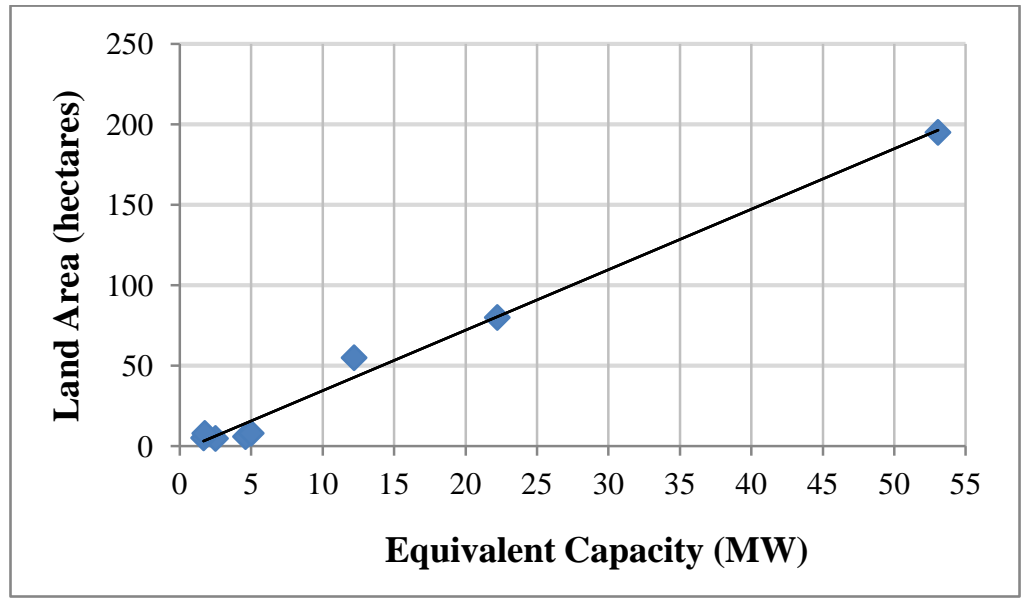

Fig. 2: Land Area vs. Equivalent Capacity for Existing Plants

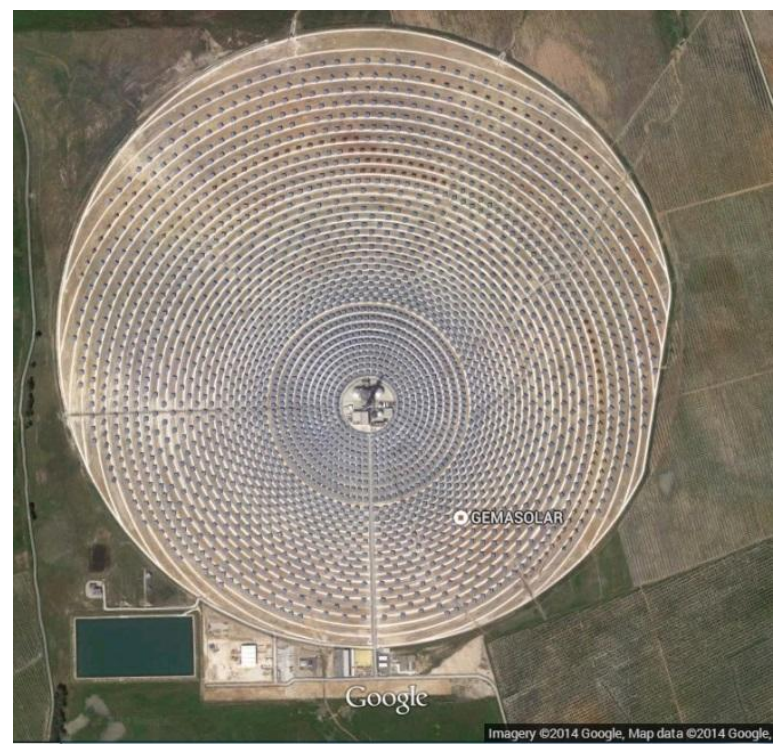

Fig. 3: Heliostat Field at the Gemasolar Plant, Spain [17] 


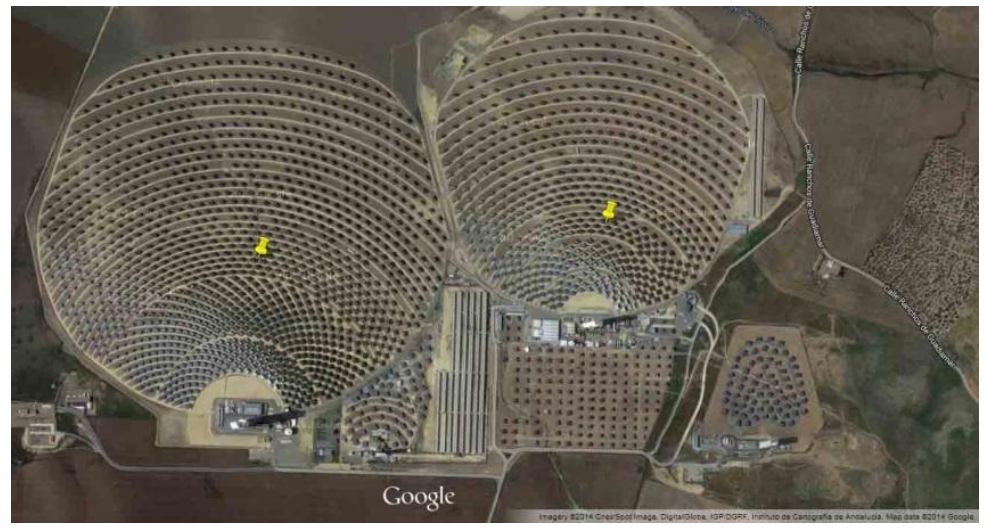

Fig. 4: The Heliostat Field for PS 10 and PS 20, Spain [18]

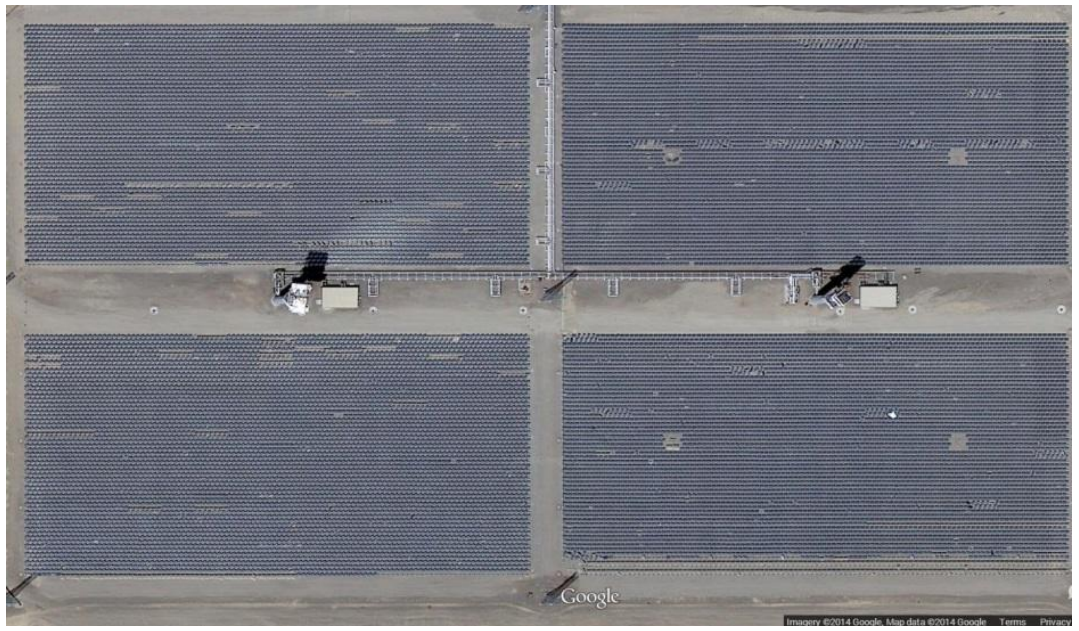

Fig. 5: Heliostat Field at the Sierra Sun Tower, USA [19]

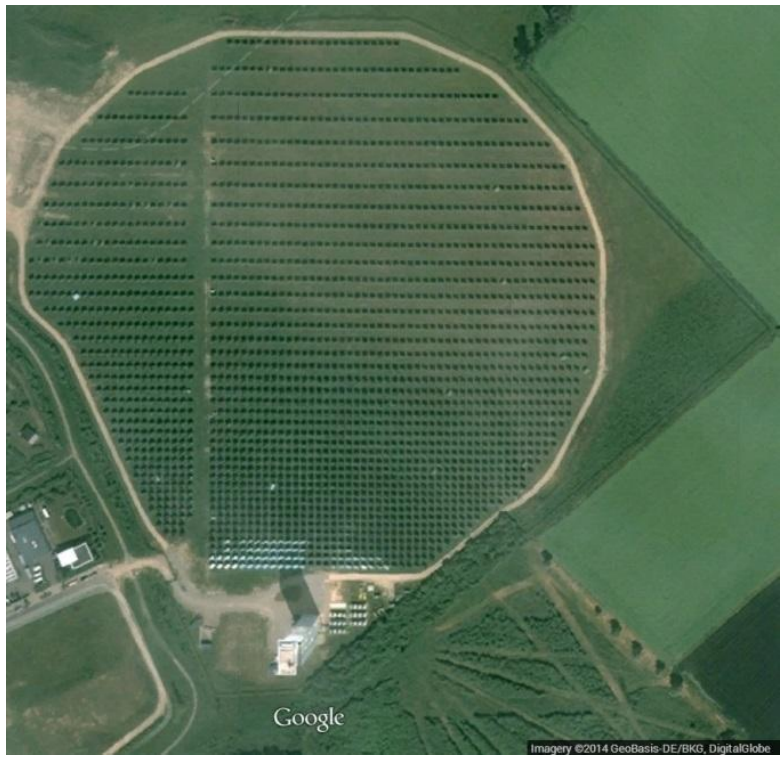

Fig. 6: Heliostat Field of the Jülich plant, Germany [20] 


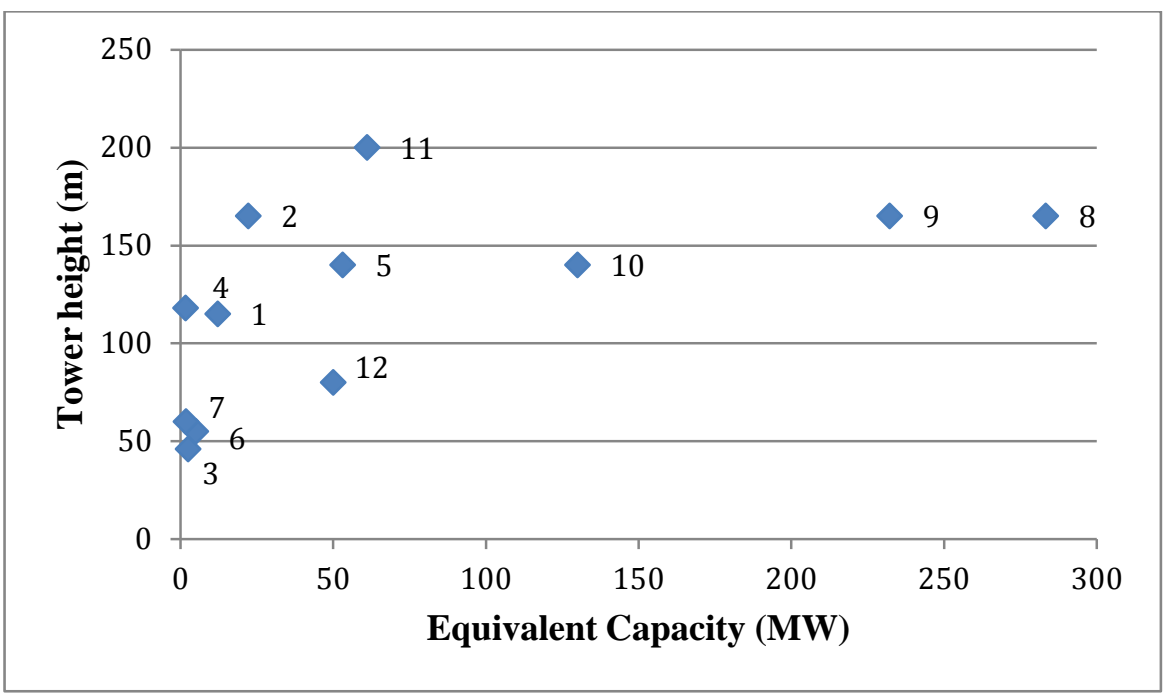

Fig. 7: Variation of Tower Height with Equivalent Capacity
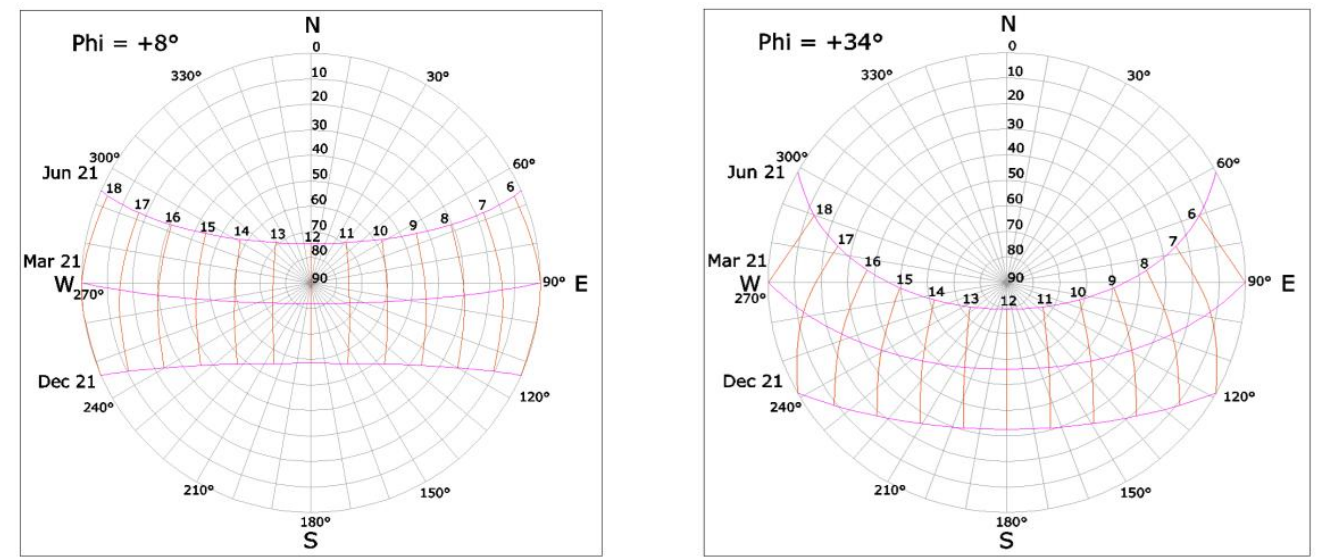

Fig. 8: Nomogram Showing the Path of the Sun 


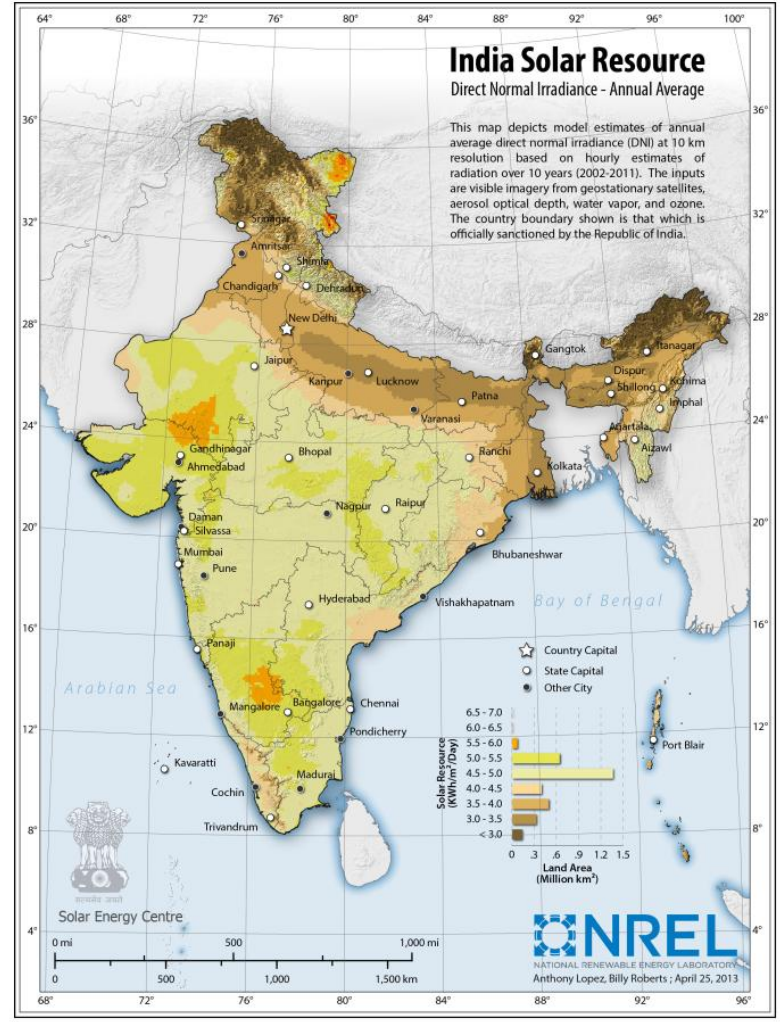

Fig. 9: Annual DNI Map for India [37] 
Table 1: Global Status of ST and PT CSP plants [1]

\begin{tabular}{ccc}
\hline Technology & Solar Tower & Parabolic Trough \\
\hline $\begin{array}{c}\text { Operating Plants Capacity } \\
\text { (MW) }\end{array}$ & 457 & 1168 \\
$\begin{array}{c}\text { Under Construction Capacity } \\
\text { (MW) }\end{array}$ & 1197 & 1377 \\
\hline
\end{tabular}

Table 2: JNNSM Capacity Addition Targets [12]

\begin{tabular}{cccc}
\hline $\begin{array}{c}\text { JNNSM Policy Targets } \\
\text { (Cumulative)/Year }\end{array}$ & $\begin{array}{c}\text { Phase 1 } \\
(\mathbf{2 0 1 0 - 1 3 )}\end{array}$ & $\begin{array}{c}\text { Phase 2 } \\
(\mathbf{2 0 1 3 - 1 7 )}\end{array}$ & $\begin{array}{c}\text { Phase 3 } \\
\mathbf{( 2 0 1 7 - 2 2})\end{array}$ \\
\hline Utility Grid Power (MW) & 1100 & 10000 & 20000 \\
Off-Grid Solar Application (MW) & 200 & 1000 & 2000 \\
\hline
\end{tabular}


Table 3: Information on Operational Plants [13]

\begin{tabular}{|c|c|c|c|c|c|c|c|c|c|c|c|}
\hline Plant Name & Country & $\begin{array}{l}\text { Capacity } \\
\text { (MW) }\end{array}$ & $\begin{array}{l}\text { Storage } \\
\text { (hours) }\end{array}$ & $\begin{array}{l}\text { Land Area } \\
\text { (hectares) }\end{array}$ & $\begin{array}{l}\text { Number of } \\
\text { Heliostats }\end{array}$ & $\begin{array}{c}\text { Heliostat } \\
\text { Aperture } \\
\text { Area } \\
\left(\mathrm{m}^{2}\right) \\
\end{array}$ & $\begin{array}{c}\text { Solar Field } \\
\text { Aperture } \\
\text { Area }\left(\mathrm{m}^{2}\right)\end{array}$ & $\begin{array}{c}\text { Tower } \\
\text { Height } \\
\text { (m) }\end{array}$ & $\begin{array}{l}\text { Receiver } \\
\text { type }\end{array}$ & HTF & $\begin{array}{l}\text { Year of Start } \\
\text { of Operation }\end{array}$ \\
\hline PS 10 & Spain & 10 & 1 & 55 & 624 & 120 & 75000 & 115 & Cavity & Water & 2007 \\
\hline Jülich & Germany & 1.5 & 1.5 & 8 & 2153 & 8 & 18000 & 60 & Volumetric & Air & 2008 \\
\hline PS 20 & Spain & 20 & 1 & 80 & 1255 & 120 & 150000 & 165 & Cavity & Water & 2009 \\
\hline Sierra Suntower & USA & 5 & 0 & 8.1 & 24360 & 1.14 & 27670 & 55 & $\begin{array}{l}\text { Dual Cavity } \\
\text { and External } \\
\text { Rectangular }\end{array}$ & Water & 2009 \\
\hline $\begin{array}{l}\text { Gemasolar } \\
\text { Thermosolar }\end{array}$ & Spain & 20 & 15 & 195 & 2650 & 120 & 318000 & 140 & $\begin{array}{l}\text { External } \\
\text { Cylindrical }\end{array}$ & $\begin{array}{l}\text { Molten } \\
\text { Salt }\end{array}$ & 2011 \\
\hline ACME & India & 2.5 & 0 & 4.8 & 14280 & 1.14 & 16222 & 46 & Cavity & Water & 2011 \\
\hline Dahan & China & 1.5 & 1 & 5.2 & 100 & 100 & 10000 & 118 & Cavity & Water & 2013 \\
\hline Solugas & Spain & 4.6 & 0 & 6 & 69 & 121 & 8349 & 75 & Cavity & Air & 2012 \\
\hline $\begin{array}{l}\text { Ivanpah Solar } \\
\text { Tower }\end{array}$ & USA & 392 & 0 & 1417 & 173500 & 14.08 & 2295960 & 140 & $\begin{array}{c}\text { External } \\
\text { Rectangular }\end{array}$ & Water & 2013 \\
\hline
\end{tabular}

Table 4: Information on Plants Under Construction [13]

\begin{tabular}{|c|c|c|c|c|c|c|c|c|c|c|c|}
\hline $\begin{array}{l}\text { Plant } \\
\text { Name }\end{array}$ & Country & $\begin{array}{c}\text { Capacity } \\
\text { (MW) }\end{array}$ & $\begin{array}{l}\text { Storage } \\
\text { (hours) }\end{array}$ & $\begin{array}{l}\text { Land Area } \\
\text { (hectares) }\end{array}$ & $\begin{array}{l}\text { Number of } \\
\text { Heliostats }\end{array}$ & $\begin{array}{l}\text { Heliostat } \\
\text { Aperture } \\
\text { Area }\left(\mathrm{m}^{2}\right)\end{array}$ & $\begin{array}{l}\text { Heliostat } \\
\text { solar } \\
\text { Field } \\
\text { Aperture } \\
\text { Area }\left(\mathrm{m}^{2}\right) \\
\end{array}$ & $\begin{array}{c}\text { Tower } \\
\text { Height } \\
\text { (m) }\end{array}$ & $\begin{array}{l}\text { Receiver } \\
\text { type }\end{array}$ & HTF & $\begin{array}{l}\text { Expected } \\
\text { year of } \\
\text { start of } \\
\text { operation }\end{array}$ \\
\hline $\begin{array}{l}\text { Crescent } \\
\text { Dunes }\end{array}$ & USA & 110 & 10 & 648 & 17170 & 62.4 & 1000000 & 165 & $\begin{array}{c}\text { External } \\
\text { Cylindrical }\end{array}$ & $\begin{array}{l}\text { Molten } \\
\text { Salt }\end{array}$ & 2014 \\
\hline Rice Solar & USA & 150 & 8 & 571 & 17170 & 62.4 & 1000000 & 165 & $\begin{array}{l}\text { External } \\
\text { Cylindrical }\end{array}$ & $\begin{array}{c}\text { Molten } \\
\text { Salt }\end{array}$ & 2016 \\
\hline Khi Solar & South Africa & 50 & 2 & 140 & 4120 & 140 & 576800 & 200 & Cavity & Water & 2014 \\
\hline Supcon & China & 50 & 2.5 & 330 & 217440 & 2 & 434880 & 80 & $\begin{array}{c}\text { To Be } \\
\text { Decided }\end{array}$ & $\begin{array}{c}\text { Molten } \\
\text { Salt }\end{array}$ & 2016 \\
\hline
\end{tabular}


Table 5: Solar to Electric Conversion Efficiency for Existing Plants [13]

\begin{tabular}{|c|c|c|c|c|c|}
\hline Plant Name & $\begin{array}{c}\text { Rated } \\
\text { Capacity } \\
\left(\mathbf{M W}_{\mathrm{e}}\right)\end{array}$ & $\begin{array}{c}\text { Annual } \\
\text { Expected } \\
\text { Electricity } \\
\text { Generation } \\
\text { (MWh/year) }\end{array}$ & $\begin{array}{l}\text { Solar Resource } \\
\text { (kWh/m²/year) }\end{array}$ & $\begin{array}{l}\text { Heliostat } \\
\text { Aperture } \\
\text { Area }\left(\mathbf{m}^{2}\right)\end{array}$ & $\begin{array}{c}\text { Solar to } \\
\text { Electric } \\
\text { Conversion } \\
\text { Efficiency (\%) }\end{array}$ \\
\hline \multicolumn{6}{|c|}{ OPERATIONAL } \\
\hline \multicolumn{6}{|c|}{ Receiver Type : Cavity } \\
\hline PS 10 & 11.02 & 23400 & 2012 & 75000 & 15.51 \\
\hline PS 20 & 20 & 48000 & 2012 & 150000 & 15.9 \\
\hline Dahan & 1.5 & 1950 & 1290 & 10000 & 15.11 \\
\hline \multicolumn{6}{|c|}{ Receiver Type : External Tubular } \\
\hline Gemasolar & 19.9 & 110000 & 2172 & 318000 & 15.93 \\
\hline $\begin{array}{c}\text { Ivahpah } \\
\text { SEGS }\end{array}$ & 392 & 1079232 & 2717 & 2295960 & 17.30 \\
\hline \multicolumn{6}{|c|}{ Receiver Type : Volumetric } \\
\hline Jülich & 1.5 & 1000 & 902 & 18000 & 6.16 \\
\hline \multicolumn{6}{|c|}{ UNDER CONSTRUCTION } \\
\hline \multicolumn{6}{|c|}{ Receiver Type : External Cylindrical } \\
\hline Rice Solar & 150 & 450000 & 2598 & 1071361 & 16.17 \\
\hline $\begin{array}{l}\text { Crescent } \\
\text { Dunes }\end{array}$ & 110 & 485000 & 2685 & 1071361 & 16.86 \\
\hline
\end{tabular}


Table 6: Mirror Area Based on Capacity [13]

\begin{tabular}{|c|c|c|c|c|c|c|}
\hline \multirow[t]{2}{*}{ Plant Name } & \multirow[t]{2}{*}{$\begin{array}{l}\text { Capacity } \\
\left(\text { MWe }_{\text {e }}\right.\end{array}$} & \multirow[t]{2}{*}{$\begin{array}{l}\text { Storage } \\
\text { (hours) }\end{array}$} & \multirow[t]{2}{*}{$\begin{array}{c}\text { Equivalent Capacity } \\
\left(M_{\mathrm{e}}\right)\end{array}$} & \multirow[t]{2}{*}{$\begin{array}{c}\text { Mirror Area } \\
\left(\mathrm{m}^{2}\right)\end{array}$} & \multicolumn{2}{|c|}{$\begin{array}{c}\text { Mirror Area }\left(\mathrm{m}^{2}\right) \text { per } \mathrm{MW}_{\mathrm{e}} \\
\text { of }\end{array}$} \\
\hline & & & & & $\begin{array}{c}\text { Rated } \\
\text { Capacity }\end{array}$ & $\begin{array}{c}\text { Equivalent } \\
\text { Capacity }\end{array}$ \\
\hline \multicolumn{7}{|c|}{ Operational } \\
\hline \multicolumn{7}{|c|}{ Receiver Type : Cavity } \\
\hline PS-10 & 11.02 & 1 & 12.24 & 75000 & 6806 & 6125 \\
\hline PS-20 & 20 & 1 & 22.22 & 150000 & 7500 & 6750 \\
\hline ACME & 2.5 & 0 & 2.5 & 16279 & 6512 & 6512 \\
\hline Dahan & 1.5 & 1 & 1.667 & 10000 & 6667 & 5999 \\
\hline Solugas & 4.6 & 0 & 4.6 & 8349 & 1815 & 1815 \\
\hline \multicolumn{7}{|c|}{ Receiver Type : External Tubular } \\
\hline Gemasolar & 19.9 & 15 & 53.07 & 318000 & 15980 & 5992 \\
\hline Ivanpah & 392 & 0 & 392 & 2600000 & 6633 & 6633 \\
\hline \multicolumn{7}{|c|}{ Receiver Type : External Cylindrical and Dual Cavity } \\
\hline Sierra & 5 & 0 & 5 & 27670 & 5534 & 5534 \\
\hline \multicolumn{7}{|c|}{ Receiver Type : Volumetric } \\
\hline Jülich & 1.5 & 1.5 & 1.75 & 18000 & 12000 & 10286 \\
\hline \multicolumn{7}{|c|}{ Under Construction } \\
\hline \multicolumn{7}{|c|}{ Receiver Type : External Cylindrical } \\
\hline Rice Solar & 150 & 8 & 283.33 & 1071361 & 7142 & 3781 \\
\hline $\begin{array}{c}\text { Crescent } \\
\text { Dunes }\end{array}$ & 110 & 10 & 232.22 & 1071361 & 9740 & 4614 \\
\hline \multicolumn{7}{|c|}{ Receiver Type : Cavity } \\
\hline $\begin{array}{l}\text { Khi Solar } \\
\text { One }\end{array}$ & 50 & 2 & 61 & 58000 & 1160 & 951 \\
\hline
\end{tabular}


Table 7: Land Area Based on Capacity [13]

\begin{tabular}{|c|c|c|c|c|c|c|}
\hline \multirow[t]{2}{*}{ Plant Name } & \multirow[t]{2}{*}{$\begin{array}{c}\text { Capacity } \\
\left(M W_{e}\right)\end{array}$} & \multirow[t]{2}{*}{$\begin{array}{l}\text { Storage } \\
\text { (hours) }\end{array}$} & \multirow{2}{*}{$\begin{array}{c}\text { Equivalent } \\
\text { Capacity } \\
\left(\mathrm{MW}_{\mathrm{e}}\right)\end{array}$} & \multirow[t]{2}{*}{$\begin{array}{l}\text { Land Area } \\
\text { (hectares) }\end{array}$} & \multicolumn{2}{|c|}{ Land Area (hectares) per MWe } \\
\hline & & & & & Rated Capacity & $\begin{array}{c}\text { Equivalent } \\
\text { Capacity }\end{array}$ \\
\hline \multicolumn{7}{|c|}{ Operational } \\
\hline \multicolumn{7}{|c|}{ Receiver Type : Cavity } \\
\hline PS-10 & 11.02 & 1 & 12.24 & 55 & 5 & 4.5 \\
\hline PS-20 & 20 & 1 & 22.22 & 80 & 4 & 3.6 \\
\hline ACME & 2.5 & 0 & 2.5 & 4.85 & 2.8 & 1.9 \\
\hline Dahan & 1.5 & 1 & 1.667 & 5.2 & 3.4 & 3.1 \\
\hline Solugas & 4.6 & 0 & 4.6 & 6 & 1.3 & 1.3 \\
\hline \multicolumn{7}{|c|}{ Receiver Type : External } \\
\hline Gemasolar & 19.9 & 15 & 53.07 & 195 & 9.7 & 3.7 \\
\hline Ivanpah & 392 & 0 & 392.0 & 1417 & 3.6 & 3.6 \\
\hline \multicolumn{7}{|c|}{ Receiver Type : External Cylindrical and Dual Cavity } \\
\hline Sierra & 5 & 0 & 5.0 & 8.1 & 1.6 & 1.6 \\
\hline \multicolumn{7}{|c|}{ Receiver Type : Volumetric } \\
\hline Jülich & 1.5 & 1.5 & 1.75 & 8 & 5.3 & 4.6 \\
\hline \multicolumn{7}{|c|}{ Under Construction } \\
\hline \multicolumn{7}{|c|}{ Receiver Type : External Cylindrical } \\
\hline Rice Solar & 150 & 8 & 283.33 & 571 & 3.8 & 2 \\
\hline Crescent & 110 & 10 & 232.22 & 648 & 5.9 & 2.8 \\
\hline \multicolumn{7}{|c|}{ Receiver Type : Cavity } \\
\hline $\begin{array}{c}\text { Khi Solar } \\
\text { One }\end{array}$ & 50 & 2 & 61 & 140 & 2.8 & 2.3 \\
\hline \multicolumn{7}{|c|}{ Receiver Type : To be Decided } \\
\hline $\begin{array}{c}\text { Supcon } \\
\text { Tower }\end{array}$ & 50 & 2.5 & 50 & 330 & 6.6 & 6.6 \\
\hline
\end{tabular}

Table 8: Packing Density of ST plants

\begin{tabular}{ccc}
\hline Plant Name & $\begin{array}{l}\text { Packing Density } \\
\text { Percentage (\%) }\end{array}$ & r/h \\
\hline \multicolumn{2}{c}{ Field Configuration: Surround field (Radial) } \\
\hline Gemasolar & 16.3 & 6.2 \\
Crescent Dunes & 16.5 & 9.7 \\
ISEGS & 16.4 & 10.4 \\
\hline \multicolumn{3}{c}{ Field Configuration: Single side field } \\
\hline PS 10 & 13.6 & 6.5 \\
PS 20 & 18.8 & 5.6 \\
\hline \multicolumn{3}{c}{ Field Configuration: Cornfield } \\
\hline Sierra Suntower & 34.2 & 2.3 \\
Jülich & 22.5 & 2.3 \\
\hline
\end{tabular}


Table 9: Advantages and Limitations of HTFs

\begin{tabular}{|c|c|c|}
\hline HTF & Advantages & Limitations \\
\hline Water & $\begin{array}{l}\text {-For steam Rankine cycle, water being the } \\
\text { working fluid, the need for heat exchanger is } \\
\text { eliminated } \\
\text {-Eliminates the costs associated with the salt or } \\
\text { oil based HTFs }\end{array}$ & $\begin{array}{l}\text {-Dissimilar heat transfer coefficients in liquid, } \\
\text { saturated vapour and superheated gas phases } \\
\text {-Consequent problems with temperature gradient } \\
\text { and thermal stress } \\
\text {-Flow control problems with varying solar flux } \\
\text {-Difficult for long thermal storage hours }\end{array}$ \\
\hline $\begin{array}{l}\text { Molten } \\
\text { Salt }\end{array}$ & $\begin{array}{l}\text {-Stable, non-toxic and environmentally benign } \\
\text {-High thermal conductivity and thermal } \\
\text { capacity } \\
\text {-Operating temperatures can go up to } 560^{\circ} \mathrm{C}\end{array}$ & $\begin{array}{l}\text {-High melting point }\left(\sim 222^{\circ} \mathrm{C}\right) \text {; Needs auxiliary } \\
\text { heating to prevent solidification } \\
\text {-Highly corrosive at elevated temperatures }\end{array}$ \\
\hline Air & $\begin{array}{l}\text {-High temperatures of the order of } 1000^{\circ} \mathrm{C} \text { can } \\
\text { be utilized }\end{array}$ & $\begin{array}{l}\text {-Poor heat transfer properties (conductivity, film } \\
\text { coefficient etc.) compared to other fluids } \\
\text {-Complex receiver design }\end{array}$ \\
\hline
\end{tabular}


Table 10: Receiver Size Estimation

\begin{tabular}{|c|c|c|c|c|c|c|c|c|c|c|c|}
\hline Plant Name & $\begin{array}{l}\text { Equivalent } \\
\text { Capacity } \\
\text { (MW) }\end{array}$ & $\begin{array}{c}\text { Power } \\
\text { Block } \\
\text { Inlet } \\
\text { Temp } \\
\left.{ }^{\circ} \mathrm{C}\right)\end{array}$ & $\begin{array}{c}\text { Power } \\
\text { Block } \\
\text { Efficiencya } \\
(\%)\end{array}$ & $\begin{array}{c}\text { Power input } \\
\text { to Power } \\
\text { Block } \\
\left(\mathrm{MW}_{\text {th }}\right)\end{array}$ & $\begin{array}{l}\text { Power input } \\
\text { to Receiver } \\
\left(\mathrm{MW}_{\text {th }}\right)\end{array}$ & HTF & $\begin{array}{c}\text { Max. } \\
\text { Allowable } \\
\text { Flux Density } \\
\text { for HTF } \\
\left(\mathbf{k W} / \mathbf{m}^{2}\right)\end{array}$ & $\begin{array}{c}\text { Flux on } \\
\text { Receiver } \\
\left(\mathrm{kW} / \mathbf{m}^{2}\right)\end{array}$ & $\begin{array}{c}\text { Calculated } \\
\text { Receiver } \\
\text { Area }\left(\mathbf{m}^{2}\right)\end{array}$ & $\begin{array}{c}\text { Actual } \\
\text { Receiver } \\
\text { Area }\left(\mathbf{m}^{2}\right)\end{array}$ & $\begin{array}{c}\text { Actual } \\
\text { Area/ } \\
\text { Calculated } \\
\text { Area }\end{array}$ \\
\hline Solar Two & 13.33 & 565 & 43 & 31.01 & 36.47 & $\begin{array}{c}\text { Molten } \\
\text { Salt }\end{array}$ & 1000 & 850 & 42.91 & 99.30 & 2.31 \\
\hline Gemasolar & 53.07 & 565 & 43 & 123.41 & 145.20 & $\begin{array}{l}\text { Molten } \\
\text { Salt }\end{array}$ & 1000 & 850 & 170.82 & 251.33 & 1.47 \\
\hline PS-10 & 12.24 & 250 & 27 & 45.33 & 53.33 & Water & 350 & 300 & 177.78 & 279.54 & 1.57 \\
\hline Dahan & 1.67 & 400 & 25 & 6.68 & 7.86 & Water & 350 & 300 & 26.20 & 25 & 0.95 \\
\hline $\begin{array}{l}\text { Jülich Solar } \\
\text { Tower }\end{array}$ & 1.8 & 680 & 25 & 7.2 & 8.47 & Air & 1200 & 1020 & 8.30 & 22 & 2.65 \\
\hline Solugas & 4.6 & 850 & 30 & 15.33 & 18.04 & Air & 1200 & 1020 & 17.69 & 90.25 & 5.10 \\
\hline
\end{tabular}

a These are assumed values [22] 
Table 11: Tower Height and Distance of the Farthest Heliostat from the Tower

\begin{tabular}{|c|c|c|c|c|c|}
\hline $\begin{array}{c}\text { Sl. } \\
\text { No. }\end{array}$ & Plant & $\begin{array}{c}\text { Capacity } \\
\left(\mathbf{M W}_{\mathrm{e}}\right)\end{array}$ & $\begin{array}{c}\text { TES } \\
\text { (hours) }\end{array}$ & $\begin{array}{c}\text { Equivalent } \\
\text { Capacity } \\
\left(\text { MW }_{\mathrm{e}}\right)\end{array}$ & $\begin{array}{c}\text { Tower } \\
\text { Height } \\
\text { (m) }\end{array}$ \\
\hline \multicolumn{6}{|c|}{ Operational } \\
\hline \multicolumn{6}{|c|}{ Receiver Type : Cavity } \\
\hline 1 & PS 10 & 11 & 1 & 12.2 & 115 \\
\hline 2 & PS 20 & 20 & 1 & 22.2 & 165 \\
\hline 3 & ACME & 2.5 & 0 & 2.5 & 46 \\
\hline 4 & Dahan & 1.5 & 1 & 1.667 & 118 \\
\hline \multicolumn{6}{|c|}{ Receiver Type : External Tubular } \\
\hline 5 & Gemasolar & 19.9 & 15 & 53.1 & 140 \\
\hline 6 & ISEGS & 130 & 0 & 130 & 140 \\
\hline \multicolumn{6}{|c|}{ Receiver Type : External Cylindrical and Dual Cavity } \\
\hline 7 & Sierra & 5 & 0 & 5 & 55 \\
\hline \multicolumn{6}{|c|}{ Receiver Type : Volumetric } \\
\hline 8 & Jülich & 1.5 & 1.5 & 1.8 & 60 \\
\hline \multicolumn{6}{|c|}{ Under Construction } \\
\hline \multicolumn{6}{|c|}{ Receiver Type : External Cylindrical } \\
\hline 9 & Rice Solar & 150 & 8 & 283.3 & 165 \\
\hline 10 & $\begin{array}{c}\text { Crescent } \\
\text { dunes }\end{array}$ & 110 & 10 & 232.2 & 165 \\
\hline \multicolumn{6}{|c|}{ Receiver Type : Cavity } \\
\hline 11 & $\begin{array}{c}\text { Khi Solar } \\
\text { One }\end{array}$ & 50 & 2 & 61.1 & 200 \\
\hline \multicolumn{6}{|c|}{ Receiver Type : To be Decided } \\
\hline 12 & Supcon & 50 & 2.5 & 5 & 80 \\
\hline
\end{tabular}

Table 12: Available Gross Costs of Plants

\begin{tabular}{ccccc}
\hline Plant & Capacity & $\begin{array}{c}\text { TES } \\
\text { (hours) }\end{array}$ & $\begin{array}{c}\text { Equivalent } \\
\text { Capacity } \\
\text { (MW) }\end{array}$ & $\begin{array}{c}\text { Cost/ Capacity (Rs. } \\
\text { crore/MW) }\end{array}$ \\
\hline Dahan & 1.5 & 1 & 1.67 & 19.76 \\
PS 10 & 11.02 & 1 & 12.2 & 18.62 \\
Gemasolar & 20 & 15 & 53.3 & 36.44 \\
\hline
\end{tabular}

